https://www.journal-imab-bg.org

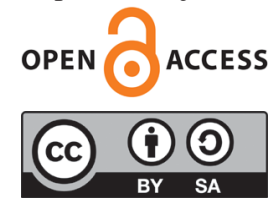

Original article

\title{
SPECIFIC MICROBIOLOGY SPECTRUM OF WHITE SAND MUSSELS FROM KEY SAMPLE SPOTS FROM BULGARIAN BLACK SEA AQUATORY
}

Borislava K. Pavlova ${ }^{1}$, Sevginar F. Ibryamova ${ }^{1}$, Darina Bachvarova ${ }^{1}$, Dimitar D. Doichev ${ }^{1}$, Elitza Tz. Stanachkova ${ }^{1}$, Seniha Salim ${ }^{1}$, Nikolay D. Natchev ${ }^{1,2}$, Tsveteslava V. Ignatova-Ivanova ${ }^{1 *}$

1) Department of Biology, Shumen University, Shumen, Bulgaria.

2) Department of Integrative Zoology, Vienna University, Austria.

\begin{abstract}
:
The "white sand mussels" are edible bivalves inhabiting the littoral shores usually buried in the sand. They are invasive species for the Bulgarian waters of the Black Sea. The samples for this study were collected from different points on the northern and southern Black Sea Bulgarian coast in the period January 2020 to December 2020. The study of different types of microorganisms was performed by using the microbial identification system model: MicroLog M® BIO45101 BiologInc and the software product GEN III. The physic-chemical parameters of the waters - temperature, $\mathrm{pH}$, salinity and dissolved $\mathrm{O} 2$ were also determined. In the different species, we had detected specific microbiological complexes. The species Pseudomonas viridilivida and Citrobacter farmer were isolated only from Donax trunculus. The species Escherichia hermannii was found only in Mya arenaria, and Acinetobacter johnsonii was detected only in Chamelea gallina. The isolated species Acinetobacter gyllenbergii and Acinetobacter johnsonii are related to humans and are indicators for pollution of the water with channel waste waters. Our results demonstrated an increase of the quantity of the coliforms in the region of Sveti Vlas from August, where they were 50 the norms. In the region of Arkutino in July and Ahtopol in August, the quantity of the fecal coliforms is 190 and 30 times the norms prescribed in the Ordinance No. 4 from 20.10.2000 for the quality of fisheries water and the breeding of shellfish (the amount of fecal coliforms in the intershell content should be less than 300 NVB). We noticed also a serious pollution of the Varna lake even months after an accident with a leaky pipe.
\end{abstract}

Keywords: Mya arenaria, Chamelea gallina, Donax trunculus, Black Sea, microbial identification, pathogenic,

\section{INTRODUCTION}

Òhe World Nutrition Organization recognized as edible species of the white sand mussels such as Cardium, Pecten, Tapes, Donax, Mactra, Chamelea and others, which are also found in the Black Sea. The term "white sand mussel "refers to four species of bivalve mollusks:
Chamelea gallina, Donax trunculus, Mya arenaria and Anadara kagoshimensis (National Marine Fisheries Service, 2003) [1]. Their main habitats along the Bulgarian Black Sea coast are the sublittoral sands from 0.5 to 15 $20 \mathrm{~m}$ depth. The "white sand mussel "M. arenaria L. 1758 is a bivalve shellfish found along the Danish coast, Mediterranean, Black and Azov seas. It inhabits littoral shores, usually buried in the sand (the name "arenaria" means sandy). It has a smooth, dirty-white to the yellowish shell, which is rather fragile. It grows to $130 \mathrm{~mm}$ in length and is, in fact, allochton/invasive species for the Bulgarian Black Sea coast [2]. In countries like France, Italy and Spain, the species is known under the name "telline" and is widely used as food. A very similar shellfish in Australia is locally known as "Pippies". The name Chamelea of the third species of white mussel was introduced in 1952. From 2016, the two known subspecies-the Mediterranean (C. g. gallina) and the Atlantic (C. g. striatula), were united in one species [3].

The species is often found on East Atlantic coast, Mediterranean and Black Sea. It is very typical for Adriatic Sea. It has a whitish, creamy or pale yellow color and has three characteristic reddish-brown stripes [3]. The habitat of C. gallina is below the surface of the sand, at a depth of five to twenty meters. It serves as a filter of the sea and is collecting and storing bacteria, microalgae and small particles of detritus. According to Regulation No. 1967/(2006) of the European Union [4], trade in mussels with a length of less than 25 millimeters is prohibited. The full list of prohibited marine species is available as an annex to the Habitats Directive.

The "white sand mussels" are considered a delicacy in many countries and are consumed especially during the summer season. In recent years, the mass production of white sand mussels has started on the Bulgarian coast, which has led to a sharp decrease in its population. To date, there is no literature on the microbiology of sand mussels in the Bulgarian Black Sea aquatory. In the Bulgarian section of the Black sea can be found three other mussels which are already an object of consummation: the Black mussel (Mytilus galloprovincialis), the Striped 
venus clam (C. gallina) and the Wedge clam (D.x trunculus) [5].

The present work is reporting on our results concerning the microbiology and habitat specifics in the "white sand mussel" from the species $M$. arenaria, $C$. gallina and D. trunculus.

\section{MATERIAL AND METHODS}

The study was conducted at the Department of Biology at the University of Shumen, Bulgaria. The samples were collected from the regions of Varna Lake (43.17777 N; 27.91212 E), Sveti Vlas (42.70833 N; 27.7592 E), Sozopol (42.4228 N;27.64587 E), Arkutino (42.332963 N; $27.732587 \mathrm{E})$ and Ahtopol (42.101765 N; $27.933293 \mathrm{E})$ in the period of January 2020 to December 2020 (Fig. 1).

Fig. 1. Sampling locations at the Black sea coast.

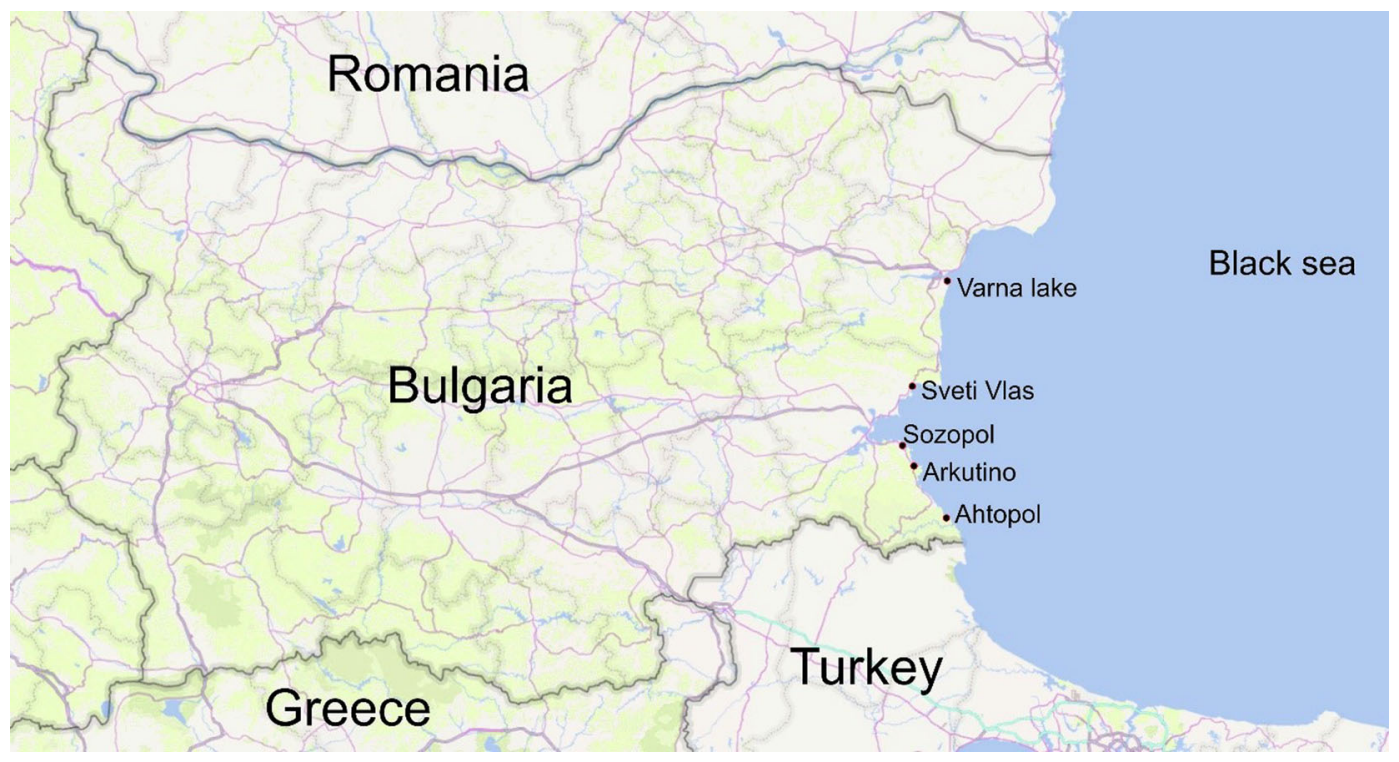

\section{Collection of the samples}

The mussels were harvested from the Bulgarian Black Sea aquatory. After collection, the samples (about $2 \mathrm{~kg}$ ) were immediately refrigerated $\left(4^{\circ} \mathrm{C}\right)$ and transported to the laboratory for the further analyses.

In this study, we examined mussels of similar size, weight, and shape to ensure maximal uniformity in the applied methods [6]. The average length of mussels used in the study was $2.2 \pm 0.43 \mathrm{~cm}$.

Physico-chemical analysis of the inhabited waters

During the mussel sampling, we measured in situ the temperature, total salinity (by using YSI Model 33 salinity meter), and pH (by using ATC Piccolo HI1280 pHmeter).

\section{Microbiological analysis}

Three subsamples (each of about $1 \mathrm{~kg}$ of mussels) were used for the microbiological analyses. The mussels were scrubbed free of dirt, washed in hypochlorite solution (20 mg 1-1), rinsed with sterile distilled water, and shucked with a sterile knife. Tissue liquor samples (about $100 \mathrm{~g}$ ) were homogenized [7]. Fecal coliforms were enumerated through a five tubes per dilution most probable number (MPN) series [8]. After $3 \mathrm{~h}$ at $37^{\circ} \mathrm{C}$ plus $21 \mathrm{~h}$ at $44^{\circ} \mathrm{C}$, gas positive tubes were recorded for F.C. From each F.C. gas positive tubes, $0.1 \mathrm{ml}$ were transferred in tubes with $10 \mathrm{ml}$ of Tryptone Water (Oxoid, Basingstoke, U.K.) and then incubated for $24 \mathrm{~h}$ at $44{ }^{\circ} \mathrm{C}$. E. coli was enumer- ated by MacConkey agar (Merck, Darmstadt, Germany). The plates very incubated aerobically at $35-37^{\circ} \mathrm{C}$ for 18 24 hours. E. coli growth; pink to red colonies with salt precipitate surrounding the colonies. Pseudomonas sp. was enumerated by Cetrimide Agar (Merck KGaA, 64271 Darmstadt, Germany).

Microbial Identification Databases for the "Biolog" Systems

The microbial identification was performed by a manual microbial identification system Biologist VIO45101AM. The isolated strains were screened on BL4021502 Tryptic Soy Agar (TCA), cultured for 24 hours at $37^{\circ} \mathrm{C}$ and then subjected to Gen III plaque identification to identify Gram positive and Gram negative aerobic bacteria. The microscopic pictures were performed using stereomicroscope OPTIKA (Italy) with a DinoEye, Eyepiece camera with 5 megapixels. The photographs were performed by using a Canon EOS 60D camera.

\section{RESULTS}

The microorganisms were isolated from $M$. arenaria, C. gallina and D. trunculus collected from two sample sites of North Bulgarian Black Sea aquatory. After $24 \mathrm{~h}$ of cultivation on different media, various microbial colonies were obtained. Data are represented on Table 1, Figures 2 and 3. 
Table 1. Number of obtained colonies on different media.

\begin{tabular}{|c|c|c|c|c|c|}
\hline $\begin{array}{l}\text { Region/mussel } \\
\text { species }\end{array}$ & $\begin{array}{l}\text { Pseudomonas } \\
\text { agar }\end{array}$ & $\begin{array}{l}\text { Cetrimid } \\
\text { agar }\end{array}$ & $\begin{array}{l}\text { Chromokult } \\
\text { agar }\end{array}$ & $\begin{array}{l}\text { MacConkey } \\
\text { agar }\end{array}$ & $\begin{array}{l}\text { strain } \\
\text { BIOLOG }\end{array}$ \\
\hline $\begin{array}{l}\text { Sozopol } \\
\text { 12.01.2020/ } \\
\text { D. trunculus }\end{array}$ & $110.10^{5}$ & $202.10^{5}$ & 105.104 & & $\begin{array}{l}\text { Enterobacter } \\
\text { cancerogenus }\end{array}$ \\
\hline $\begin{array}{l}\text { Sozopol } \\
\text { 19.11.2020/ } \\
\text { D. trunculus }\end{array}$ & $24.10^{4}$ & & & & $\begin{array}{l}\text { Myroides } \\
\text { odoratimimus }\end{array}$ \\
\hline $\begin{array}{l}\text { Saint Vlas } \\
\text { 02.03.2020/ } \\
\text { D. trunculus }\end{array}$ & $132.10^{3}$ & $120.10^{3}$ & & & $\begin{array}{l}\text { Pseudomonas } \\
\text { viridilivida }\end{array}$ \\
\hline $\begin{array}{l}\text { Saint Vlas beach } \\
14.08 .2020 / \\
\text { C. gallina }\end{array}$ & $53.10^{4}$ & & $8.10^{3}$ & $15.10^{3}$ & $\begin{array}{l}\text { Escherichia colt } \\
\text { Acinetobacter } \\
\text { gyllenbergii }\end{array}$ \\
\hline $\begin{array}{l}\text { Varna lake } \\
\text { 06.03.2020/ } \\
\text { D. trunculus }\end{array}$ & & $20.10^{3}$ & & & $\begin{array}{l}\text { Staphylococcus } \\
\text { lugdunensis }\end{array}$ \\
\hline $\begin{array}{l}\text { Varna lake } \\
\text { 05.06.2020/ } \\
\text { D. trunculus }\end{array}$ & & & $123.10^{4}$ & & $\begin{array}{l}\text { Pseudomonas } \\
\text { viridilivida }\end{array}$ \\
\hline $\begin{array}{l}\text { Arkutino } \\
17.05 .2020 / \\
\text { Chamelea gallina }\end{array}$ & & & $84.10^{3}$ & & $\begin{array}{l}\text { Enterococcus } \\
\text { hirae }\end{array}$ \\
\hline $\begin{array}{l}\text { Arkutino } \\
\text { 20.06.2020/ } \\
\text { D. trunculus }\end{array}$ & & & 3.103 & $17.10^{3}$ & $\begin{array}{l}\text { Enterococcus } \\
\text { hirae }\end{array}$ \\
\hline $\begin{array}{l}\text { Arkutino } \\
25.07 .2020 / \\
\text { D. trunculus }\end{array}$ & & & & $160.10^{3}$ & $\begin{array}{l}\text { Escherichia } \\
\text { vulneris }\end{array}$ \\
\hline $\begin{array}{l}\text { Arkutino } \\
25.08 .20 \\
\text { D. trunculus }\end{array}$ & & & $58.10^{3}$ & & $\begin{array}{l}\text { Enterococcus } \\
\text { hirae }\end{array}$ \\
\hline $\begin{array}{l}\text { Arkutino } \\
02.09 .2020 \\
\text { D. trunculus }\end{array}$ & & & $34.10^{3}$ & & $\begin{array}{l}\text { Citrobacter } \\
\text { farmeri }\end{array}$ \\
\hline $\begin{array}{l}\text { Arkutino } \\
17.10 .2020 / \\
\text { D. trunculus }\end{array}$ & & & & $92.10^{5}$ & $\begin{array}{l}\text { Acinetobacter } \\
\text { gyllenbergii }\end{array}$ \\
\hline $\begin{array}{l}\text { Ahtopol } \\
20.09 .2020 \\
\text { D. trunculus }\end{array}$ & & & & $100.10^{3}$ & $\begin{array}{l}\text { Escherichia } \\
\text { hermannii }\end{array}$ \\
\hline $\begin{array}{l}\text { Ahtopol } \\
17.10 .2020 \\
\text { D. trunculus }\end{array}$ & & & & $102.10^{4}$ & $\begin{array}{l}\text { Acinetobacter } \\
\text { johnsonii }\end{array}$ \\
\hline $\begin{array}{l}\text { Ahtopol } \\
18.11 .2020 \\
\text { D. trunculus }\end{array}$ & $91.10^{5}$ & & & & $\begin{array}{l}\text { Pseudomonas } \\
\text { alcaligenes }\end{array}$ \\
\hline $\begin{array}{l}\text { Ahtopol } \\
14.12 .2020 \\
\text { D. trunculus }\end{array}$ & $100.10^{5}$ & & & & $\begin{array}{l}\text { Pseudomonas } \\
\text { viridilivida }\end{array}$ \\
\hline $\begin{array}{l}\text { Varna Lake } \\
20.09 .2020 \\
\text { M. arenaria }\end{array}$ & & & & $98.10^{6}$ & $\begin{array}{l}\text { Escherichia } \\
\text { hermannii }\end{array}$ \\
\hline $\begin{array}{l}\text { Varna Lake } \\
20.09 .2020 \\
\text { Chamelea gallina }\end{array}$ & & & & $101.10^{6}$ & $\begin{array}{l}\text { Acinetobacter } \\
\text { johnsonii }\end{array}$ \\
\hline
\end{tabular}


The values observed for Fecal coliforms (F.C.) were confirmed also for E. cancerogenus, E. hirae, E. coli, E. vulneris and E. hermannii (Table 1 and Figs. 3 B and C). The peak of E. cancerogenus was observed in January in the region of Sozopol. E. coli in largest quantities was detected in August in the region of Sveti Vlas; E. vulneris peaked in July in the Arkutino area; E. hermannii reached its peak in September and was found only in the species $M$. arenaria from the area of Varna Lake (indicating the presence of particular environmental conditions, which influenced the quality of the mussels harvested in that month). High amounts of Pseudomonas viridilivida and $P$. alcaligenes were found in March in the region of Sveti Vlas and in November and December in the region of Ahtopol. Probably this species develops at lower water temperatures. $P$. viridilivida was also reported in the region of Varna in June. Pseudomonas $s p$. were isolated only from $D$. trunculus. Citrobacter farmer discovered in September in the Arkutino area belongs to the family Enterobacteriaceae. This species is also found only in D. trunculus. Acinetobacter gyllenbergii and A. johnsonii were found in the autumn months of September and October. A. gyllenbergii is characteristic for the species $D$. trunculus, and the species A. johnsonii is characteristic for C. gallina.

Fig. 2. Photographs of colonies of isolated species: a) colonies of P. viridilivida on media Pseudomonas agar b) colonies of E. cancerogenus on media MacConkey agar; c) colonies of E. hermannii on media Hromokult.

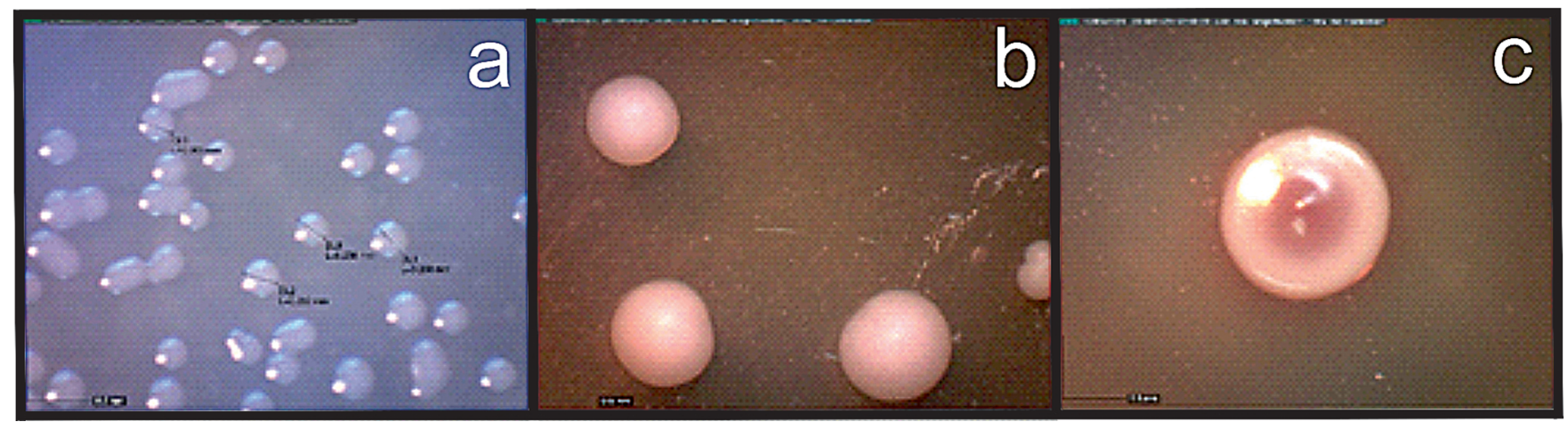

Fig. 3. Diagram from a test with the Microbial identification system Biologist VIO45101AM, demonstrating presence of A. gyllenbergii.

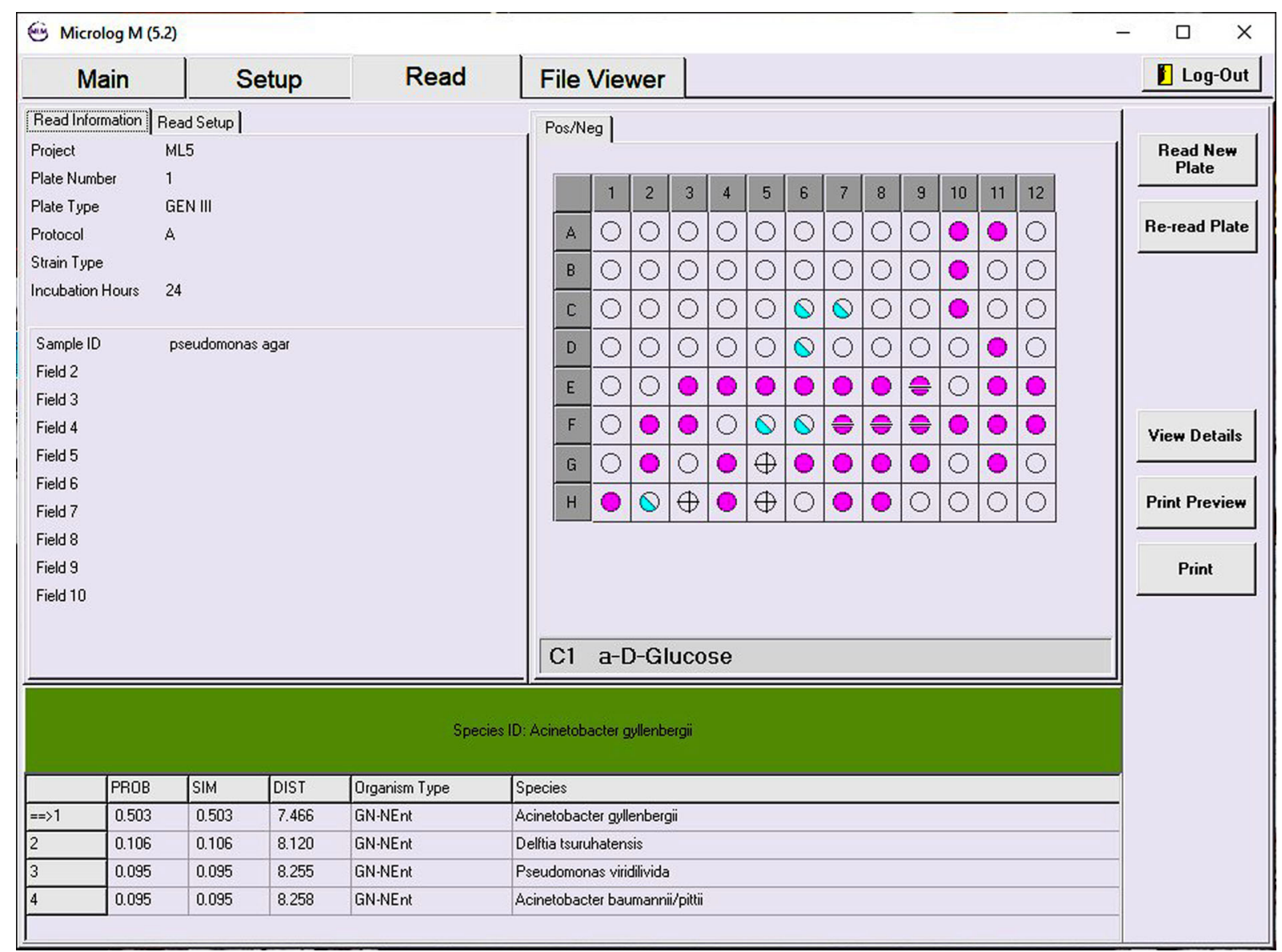


Parallel to the performance of the microbiological experiments, we conducted a physicochemical analysis of the sea waters. The results are summarized in Table 2 .

Table 2. Physico-chemical parameters of waters.

\begin{tabular}{|l|l|l|l|l|l|l|}
\hline Region & Date & Depth & Temperature & $\mathrm{pH}$ & Salinity & Dissolved $\mathrm{O}_{2}$ \\
\cline { 3 - 7 } & & $\mathrm{m}$ & {$\left[{ }^{\circ} \mathrm{C}\right]$} & {$[\mathrm{pH}]$} & {$[\mathrm{ppt}]$} & {$[\mathrm{mg} / \mathrm{l}]$} \\
\hline Sozopol & 01.2020 & 2 to 4 & 7.9 & 7.30 & 13.7 & 7.3 \\
\hline Sozopol & 11.2020 & 2 to 4 & 18.2 & 8.27 & 13.6 & 7.1 \\
\hline Varna lake & 03.2020 & 2 to 4 & 14.6 & 7.35 & 13.5 & 8.2 \\
\hline Varna lake & 06.2020 & 2 to 4 & 25.1 & 7.36 & 13.1 & 8.8 \\
\hline Arkutino & 05.2020 & 2 to 4 & 24.4 & 7.78 & 12.2 & 7.9 \\
\hline Arkutino & 06.2020 & 2 to 4 & 25.5 & 7.32 & 13.5 & 7.7 \\
\hline Arkutino & 07.2020 & 2 to 4 & 27.2 & 8.26 & 13.5 & 7.8 \\
\hline Arkutino & 08.2020 & 2 to 4 & 27.7 & 8.36 & 11.2 & 8.07 \\
\hline Arkutino & 09.2020 & 2 to 4 & 26.2 & 8.20 & 11.2 & 8.1 \\
\hline Arkutino & 10.2020 & 2 to 4 & 25.7 & 8.13 & 11.2 & 8.1 \\
\hline Ahtopol & 09.2020 & 2 to 4 & 26.9 & 8.26 & 12.3 & 7.88 \\
\hline Ahtopol & 10.2020 & 2 to 4 & 25.6 & 8.15 & 12.3 & 7.67 \\
\hline Ahtopol & 11.2020 & 2 to 4 & 20.3 & 7.97 & 12.3 & 8.07 \\
\hline Ahtopol & 12.2020 & 2 to 4 & 17.3 & 7.20 & 12.2 & 8.1 \\
\hline Varna Lake & 09.2020 & 2 to 4 & 24.3 & 8.22 & 14.2 & 8.03 \\
\hline
\end{tabular}

\section{DISCUSSION}

Mollusks such as bivalves are widely distributed sessile filter feeders that can serve as reliable bioindicators of the aquatic pollutants [9-10]. These animals represent a valuable tool for the screening of the environmental conditions. Due to the population growth worldwide, the increase of the need for protein results in the increase of consumption of food from animal origin. Therefore, seafood stands out as a way of providing animal source foods of high quality. Within seafood, the bivalves represent animals important food resource with its recently increasing consumption in Bulgaria. The United Nations and the World Food Program declared that seafood is going to have an important role in food supply in the future due to the population growth, which is estimated to increase up to 9 billion in 2050. Actually, it is assumed that the growth in the industry of seafood is going to continue on an accelerating way [11-12].

In the area of Varna Lake were detected very high amounts of E. hermannii and A. johnsonii. which are of human origin. These findings coincide with the time of spillage of fecal water as a result of a ruptured pipe in the area of Varna Lake. According to Ordinance No. 4 from 20.10.2000 for the quality of fisheries water and the breeding of shellfish [13], the amount of fecal coliforms in the inter-shell content should be less than 300 NVB in our samples from September 2020, the values were exceeded by 300 times. According to the same ordinance, there is an increase in the number of coliforms in the region of Sveti Vlas from August, where the increase is 50 times, in the regions of Arkutino in July and Ahtopol in August, the number of coliforms is increased 190 and 30 times, respectively.

Fecal indicator bacteria. i.e. total coliforms, fecal coliforms (thermo-tolerant coliforms) and intestinal enterococci (fecal streptococci) are excreted by humans, and warm-blooded animals pass through the sewage treatment plants and survive for a certain time in the aquatic environment [14]. The coliform bacteria differ considerably in their pathogenic properties. Aside from the intestines of vertebrates and invertebrates, they can also be present in the soil. Total coliforms indicate water pollution, but this does not have to directly correlate with an anthropogenic source, while fecal coliforms are used to indicate sanitary pollution. The fecal coliforms to enterococci ratio points to the origin of pollution. A ratio lower than 1.5 indicates pollution by the run off from agricultural surfaces. while a ratio higher than 4 is typical for anthropogenic pollution [15]. At all sampling locations, the number of fecal coliforms was higher than the number of enterococci indicating a great impact of human urban pollution [15]. The isolated coliform bacteria were identified as Enterococcus sp, Enterobacter sp. and Escherichia coli.

The high concentrations of F.C. detected in the warmer months may be related to the increased metabolic activity of the mollusks. The high metabolic activity of the mussels is directly related to the increase of the temperature of the sea waters from one side (Table 2) and their biological cycle from the other. In previous investigations 
of our working group, we demonstrated experimentally. that the black mussels can be isolated two stems of lactic acid bacteria belonging to L. plantarum, which show antifungal activities [16]. For the north section of the Bulgarian Black sea aquatory, for June 2018 were reported high levels of E. coli and Pseudomonas aeroginosa [8]. The temperature of the sea waters may affect the number of the microbes by concentration of the nutrients. Similar results were reported previously [17-18].

\section{CONCLUSIONS}

When studying the microbiota of populations of different species of mussels, it is very important to know their sanitary status, as well as to determine the pathobiological basis of periodic outbreaks of diseases affecting these populations. Our results demonstrated the presence of species of microorganisms in mussels, for which there was no data in the literature. With the worldwide growth of mussel consumption, we would like to point out on the possibility of the emergence of new diseases in the near future. Such diseases may result on the interaction between the pathogen, the host and the environment. The physiological and immunological status of the mussels as a host will play a leading role in the development of bacterial diseases in bivalves.

\section{Acknowledgements:}

The contributors express their gratitude for the funding by Fund Scientific Research Bulgaria Programme Grant H31/6 KP-06-H31/6/10.12.19 the project by Shumen University project RD-08-104/30.01.2021 Department of Biology and National Program Young Scientists and Postdoctoral Students.

\section{REFERENCES:}

1. NOAA Technical report NMFS SSRF-721. National Marine Fisheries Service survey of trace elements in the fishery resource. Authors: Hall RA, Zook EG, Meaburn GM. March 1978. [Internet]

2. WoRMS taxon details. Donax trunculus Linnaeus. 1758. WoRMS. 21 December 2004. [Internet]

3. Kalkan S, Altup G. The composition of cultivable bacteria, bacterial pollution, and environmental variables of the coastal areas: an example from the Southeastern Black Sea, Turkey. Environ Monit Assess. 2020 May 11;192:356 [PubMed]

4. Council Regulation (EC) No $1967 / 2006$ of 21 December 2006 concerning management measures for the sustainable exploitation of fishery resources in the Mediterranean Sea, amending Regulation (EEC) No $2847 / 93$ and repealing Regulation (EC) No 1626/94. [Internet]

5. Panayotova V, Merdzhanova A, Dobreva D, Bratoeva K, Makedonski L. Nutritional composition, bioactive compounds and health-beneficial properties of black sea shellfish. $J$ of IMAB. 2020 Jul-Sep;26(3):32933297. [Crossref]

6. Duquesne S, Liess M, Bird DJ. Sub-lethal effects of metal exposure: Physiological and behavioral responses of the estuarine bivalve Macoma balthica. Mar Environ Res. 2004 Aug-Dec;58:(2-5):245-50. [PubMed]

7. Maffei M, Vernocchi P,
Lanciotti R, Guerzoni ME, Belletti N, Gardini F. Depuration of Striped Venus Clam (Chamelea gallina L.): Effects on Microorganisms, Sand Content, and Mortality. J Food Sci. 2009 Jan-Feb;74(1):M1-M7. [PubMed]

8. Ignatova-Ivanova Ts, Ibrjmova S, Stanachkova E, Ivanov R. Microbiological characteristic of microflora of (Mytilus galloprovincialis Lam.) in The Bulgarian Black Sea aquatory. Res J Pharm Biol Chem Sci. 2018 Jan-Feb;9(1):199-205. [Internet]

9. Venier JM, Pauly D. Trophic dynamics of a Florida Keys coral reef ecosystem. In: Lessios HA, Macintyre IG. (eds.) Proceedings of the 8th International Coral Reef Symposium, Vol. 1. Smithsonian Tropical Research Institute, Panama. 1997. p.915-920. [Internet]

10. Geers TM, Pikitch EK, Frisk MG. An original model of the northern Gulf of Mexico using Ecopath with Ecosim and its implications for the effects of fishing on ecosystem structure and maturity. Deep Sea Research. Part II: Topical Studies in Oceanography. 2016 Jul;129:319331. [Crossref]

11. Cardinale M, Osio GC, Scarcella G. Mediterranean Sea: A Failure of the European Fisheries Management System. Front Mar Sci. 2017 Mar;4:72. [Crossref]

12. Tan E, Kizilkaya B. Investigation of Heavy Metal Content of Tellina (Donax trunculus Linnaeus.
1758) in Black Sea Region (Kefken). Mar Sci Tech Bull. 2019; 8(2):69-75. [Crossref]

13. [Ordinance No. 4 of October 20, 2000, on water quality for fish farming and the breeding of shellfish organisms.] [in Bulgarian] Ministry of Environment and Water, Ministry of Agriculture and Forestry and Ministry of Health, Bulgaria. SG, no. 88 of 27.10.2000. [Internet]

14. Kirschner AK, Zechmeister TC, Kavka GG, Beiwl C, Herzig A, Mach $\mathrm{RL}$, et al. Integral strategy for evaluation of fecal indicator performance in bird-influenced saline inland waters. Appl Environ Microbiol. 2004 Dec;70(12):7396-403. [PubMed]

15. Kolarevic S, KnezevicVukcevic J, Paunovic M, Tomovic J, Gacic Z, Vukovic- Gacic B. The anthropogenic impact on water quality of the river Danube in Serbia: microbiological analysis and genotoxicity monitoring. Arch Biol Sci. Belgrade. 2011; 63(4):1209-1217. [Crossref]

16. Ibryamova S, Arhangelova N, Koynova T, Dimitrov D, Dimitrova Z, Ivanov R, et al. Antifungal Activity of Lactic Acid Bacteria. Isolated from (Mytilus galloprovincialis Lam.) in The Bulgarian Black Sea aquatory. $J$ of IMAB. 2020 Jan-Mar;26(1):28752882. [Crossref]

17. Martin CC, Svanevik CS, Lunestad BT, Sekse C, Johannessen GS. Isolation and characterisation of Shiga toxin-producing Escherichia 
coli from Norwegian bivalves. Food Microbiol. 2019 Dec;84:103268. [PubMed]

18. Tsankova G, Todorova $\mathrm{T}$ Ermenlieva N, Merdzhanova A, Panayotova V, Dobreva D, et al. Anti- bacterial activity of different extracts of black mussel (Mytilus galloprovincialis) from the Black Sea. J of IMAB. 2021 Jan-Mar;27(1): 3506-3509. [Crossref]

Please cite this article as: Pavlova BK, Ibryamova SF, Bachvarova D, Doichev DD, Stanachkova ET, Salim S, Natchev ND, Ignatova-Ivanova TV. Specific microbiology spectrum of white sand mussels from key sample spots from Bulgarian Black Sea aquatory. J of IMAB. 2021 Oct-Dec;27(4):4077-4083. DOI: https://doi.org/10.5272/jimab.2021274.4077

Received: 19/04/2021; Published online: 10/11/2021

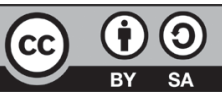

Address for correspondence:

Tsveteslava Ignatova-Ivanova

Department of Biology, Shumen University "Konstantin Preslavski"

115, Universitetska Str., Shumen, Bulgaria

E-mail: ts.ignatovaivanova@shu.bg 